\title{
PEMODELAN JUMLAH KASUS DBD YANG MENINGGAL DI KOTA PADANG DENGAN MENGGUNAKAN REGRESI POISSON
}

\author{
LILY ZUHRAT, DODI DEVIANTO, IZZATI RAHMI HG \\ Program Studi Matematika, \\ Fakultas Matematika dan Ilmu Pengetahuan Alam, Universitas Andalas, \\ Kampus UNAND Limau Manis Padang, Indonesia, \\ lilyzuhrat@ymail.com
}

\begin{abstract}
Abstrak. Demam Berdarah Dengue (DBD) adalah penyakit infeksi yang disebabkan oleh virus Dengue melalui gigitan nyamuk Aedes. Penelitian ini bertujuan untuk memperoleh model dengan metode regresi Poisson untuk jumlah kasus DBD yang meninggal di Kota Padang dan mengetahui faktor apa saja yang mempengaruhinya. Regresi Poisson ini digunakan untuk kejadian yang relatif jarang terjadi. Faktor yang diduga mempengaruhi DBD tersebut adalah faktor lingkungan, diantaranya persentase rumah sehat, persentase sarana air bersih yang memenuhi syarat, persentase rumah ber-Prilaku Hidup Bersih Sehat (ber-PHBS), persentase pengelolaan sampah yang memenuhi syarat dan persentase jamban yang memenuhi syarat. Kriteria pemilihan model terbaik yang digunakan adalah AIC dan BIC. Faktor yang berpengaruh terhadap jumlah kasus DBD yang meninggal adalah Persentase rumah sehat dan persentase rumah ber-Prilaku Hidup Bersih Sehat (ber-PHBS).

Kata Kunci: Regresi Poisson, Demam Berdarah Dengue (DBD), Maximum Likelihood Estimator(MLE)
\end{abstract}

\section{Pendahuluan}

Demam Berdarah Dengue (DBD) atau disebut juga Dengue Hemorrhagic Fever (DHF) merupakan penyakit infeksi yang disebabkan oleh virus Dengue yang ditularkan melalui gigitan nyamuk Aedes Aegypti dan Aedes Albopictus. Kedua jenis nyamuk tersebut ditemukan di daerah yang beriklim tropis dan subtropis. Negara Indonesia merupakan salah satu negara yang berada di wilayah tropis, sehingga merupakan daerah penyebaran sekaligus daerah endemis yang menyebabkan tingginya angka kesakitan di Indonesia [3].

Sumatera Barat merupakan salah satu provinsi di Indonesia yang memiliki kasus DBD yang cukup tinggi dan mendapat urutan ke-14 pada tahun 2007. Pada tahun 1972 di Sumatera Barat DBD pertama kali ditemukan di Kota Padang. Seiring dengan perkembangan transportasi dan mobilitas pada saat ini jumlah penderita DBD makin meningkat dan wilayah terjangkit makin meluas dengan terjadinya pengembangan ke Kabupaten dan Kota lainnya. Berdasarkan profil data kesehatan kota padang pada tahun 2013, tercatat bahwa jumlah kasus DBD sebanyak 998 kasus dengan kematian 9 orang dan Case Fatalily Rate $(C F R)=0,9 \%$ [6]. Karena kematian sering terjadi pada kasus DBD, maka peneliti tertarik untuk mengkaji pengaruh 
jumlah kasus DBD yang meninggal dengan faktor-faktor yang mempengaruhinya.

Jumlah kasus DBD yang meninggal dapat digolongkan sebagai percobaan Poisson, dimana terjadi dalam selang waktu tertentu atau daerah tertentu, tetapi tidak berpengaruh pada daerah lain, atau dapat juga dikatakan sebagai data diskrit. Jumlah kasus DBD yang meninggal merupakan variabel respon dan faktor lingkungan yang mempengaruhi DBD merupakan variabel prediktor, maka salah satu cara yang dapat kita lakukan untuk melihat hubungan antara variabel respon dengan variabel prediktor adalah dengan memodelkan variabel respon menggunakan analisis regresi $[2]$.

Regresi poisson merupakan analisis regresi nonlinear dari distribusi Poisson, dimana analisis ini sangat cocok dan sering digunakan dalam menganalisis data diskrit. Pada penelitian ini akan dicari pemodelan dari jumlah kasus DBD yang meninggal pada masing-masing puskesmas yang ada di Kota Padang dengan faktorfaktor yang dianggap mempengaruhi kejadiannya dengan menggunakan metode regresi Poisson.

\section{Regresi Poisson}

Generalized Linear Model (GLM) adalah sebuah pengembangan dari model linier klasik yang mengasumsikan variabel responnya berdistribusi normal. Namun sering ditemukan suatu kondisi dimana variabel responnya tidak berdistribusi normal. Untuk mengatasi kondisi seperti ini para statistikawan yang dipelopori oleh McCuallagh dan Neldar (1989) telah mengembangkan model linier yang dikenal dengan istilah Generalized Linear Model (GLM).

Terdapat tiga komponen dalam Generalized Linear Model (GLM) yaitu Random Component, Systematic Component, dan Link Function. Regresi Poisson termasuk kedalam komponen Link Function pada Generalized Linear Model (GLM) dan merupakan salah satu bentuk regresi yang menggambarkan hubungan antara variabel $Y$ dimana variabel berdistribusi Poisson dengan variabel bebas $X[6]$.

Definisi 2.1. [8] Sebaran peluang bagi peubah acak Poisson $Y$ yang menyatakan banyaknya hasil percobaan yang terjadi selama suatu selang waktu atau daerah tertentu adalah

$$
f(y, \mu)=\frac{e^{-\mu} \mu^{y}}{y !}, y=0,1,2, \cdots .
$$

Dalam hal ini $\mu$ adalah rata-rata banyaknya hasil percobaan yang terjadi selama selang waktu atau dalam daerah yang dinyatakan, dan $e=2.71828 \cdots$.

Berikut adalah hipotesis dengan menggunakan uji Kolmogorov-Smirnov:

$$
\begin{aligned}
& H_{0} \text { : data berdistribusi Poisson, } \\
& H_{1} \text { : data tidak berdistribusi Poisson. }
\end{aligned}
$$

Statistik uji yang digunakan dalam pengujian hipotesis tersebut adalah

$$
D=\max \left\{\left|F_{0}(x)-S_{n}(x)\right|, i=1,2, \cdots, n\right\},
$$


dimana;

$$
\begin{aligned}
& F_{0}: \text { nilai fungsi sebaran kumulatif, } \\
& S_{n}: \text { nilai fungsi sebaran kumulatif sampel. }
\end{aligned}
$$

Kriteria untuk pengujian ini adalah tolak $H_{0}$ jika nilai $D_{\text {hitung }}$ lebih besar dari nilai $D_{\text {tabel }}$. Jika $\alpha=0.05$ dengan banyak pengamatan $\mathrm{N}$ maka $D_{\text {tabel }}$ dirumuskan sebagai berikut [7]:

$$
D_{\text {tabel }}=\frac{1,36}{\sqrt{N}}
$$

Metode Maximum Likelihood Estimator (MLE) adalah salah satu metode penaksiran parameter yang dapat digunakan untuk menaksir parameter suatu model yang diketahui distribusinya.

Berdasarkan persamaan distribusi Poisson yang ditunjukkan pada persamaan (2.1) maka fungsi likelihood nya adalah

$$
\begin{aligned}
L(\boldsymbol{\beta}) & =\prod_{i=1}^{n} f\left(y_{i} ; \boldsymbol{\beta}\right) \\
& =\prod_{i=1}^{n} \frac{\left[\exp \left(\boldsymbol{x}_{i}^{\prime} \boldsymbol{\beta}\right]^{y_{i}} \exp \left[-\exp \left(\boldsymbol{x}_{i}^{\prime} \boldsymbol{\beta}\right)\right]\right.}{y_{i} !}
\end{aligned}
$$

Pengujian signifikansi tiap-tiap parameter dari model regresi Poisson dilakukan dengan menggunakan hipotesis sebagai berikut:

$$
\begin{aligned}
& H_{0}: \beta_{j}=0, \\
& H_{1}: \beta_{j} \neq 0, \text { untuk suatu } j, j=0,1,2, \cdots, p .
\end{aligned}
$$

Statistik uji yang digunakan untuk menguji hipotesis diatas adalah statistik uji Wald, yaitu

$$
W_{j}=\left(\frac{\widehat{\beta}_{j}}{\widehat{S E}\left(\widehat{\beta}_{j}\right)}\right)^{2}
$$

dimana

$$
\begin{gathered}
\widehat{\beta_{j}}: \text { taksiran dari parameter } \beta_{j} . \\
\frac{\widehat{S E}}{\left(\widehat{\beta}_{j}\right)} \text { : taksiran standar error dari } \widehat{\beta}_{j} .
\end{gathered}
$$

Aturan keputusan adalah $H_{0}$ ditolak pada tingkat signifikansi $\alpha$ jika $W_{j}>$ $\chi_{\alpha, v}^{2}$. Penolakan $H_{0}$ pada tingkat signifikansi $\alpha$ memberi arti bahwa parameter $\widehat{\beta}_{j}$ berpengaruh terhadap model.

Pemilihan model terbaik yang digunakan pada regresi Poisson adalah Akaike Information Criteria(AIC) dan Bayesian Information Criteria(BIC). AIC digunakan untuk menentukan model yang dapat menjelaskan data dengan jumlah parameter yang baik untuk menduga data. BIC digunakan untuk memperbaiki sifat pendugaan 
yang terlalu tinggi dari AIC. AIC dan BIC digunakan untuk melihat kecocokan model terhadap data. Nilai AIC dan BIC dapat didefinisikan sebagai berikut [1]:

$$
\begin{aligned}
& A I C=-2 \ln L(\widehat{\theta})+2 k, \\
& B I C=-2 \ln L(\widehat{\theta})+k \ln (n),
\end{aligned}
$$

dimana

$$
\begin{aligned}
L(\widehat{\theta}) & : \text { nilai likelihood, } \\
k & : \text { jumlah parameter, } \\
n & : \text { banyak data pengamatan. }
\end{aligned}
$$

Dalam sebuah model sering ditemukan masalah kecocokan model dengan data. jika dilihat dari nilai residualnya, semakin besar residualnya maka makin jauh data menyimpang dari model. Dalam hal ini nilai residual dapat diperoleh dengan rumus sebagai berikut:

$$
r_{i}=\frac{y_{i}-\mu_{i}}{\sqrt{\mu_{i}}}, i=1,2, \cdots
$$

dimana

$$
\begin{aligned}
r_{i} & : \text { Pearson residual, } \\
y_{i} & : \text { pengamatan ke-i, } \\
\mu_{i}: & \text { nilai taksiran ke-i. }
\end{aligned}
$$

Misalkan $X_{j}$ adalah variabel prediktor kontinu ke- $j$. Maka untuk kenaikan satu unit nilai $x_{j}$ diperoleh:

$$
\ln \left(\mu\left(x_{1}, x_{2}, \cdots,\left(x_{j}+1\right), \cdots, x_{p}\right)\right)=\beta_{0}+\beta_{1} x_{1}+\cdots+\beta_{j}\left(x_{j}+1\right)+\cdots+\beta_{p} x_{p}
$$

Parameter $\beta_{j}$ menunjukkan selisih log nilai harapan $Y$ antara sesudah dan sebelum terjadinya kenaikan satu unit $x_{j}$ dengan asumsi nilai-nilai variabel prediktor lainnya tetap sehingga diperoleh:

$$
\ln \frac{\mu\left(x_{1}, \cdots,\left(x_{j}+1\right), \cdots, x_{p}\right)}{\left(\mu\left(x_{1}, \cdots, x_{j}, \cdots, x_{p}\right)\right)}=\beta_{j}
$$

Rasio nilai harapan $Y$ antara sesudah dan sebelum kenaikan satu unit $x_{j}$ dengan asumsi nilai variabel prediktor lainnya tetap adalah:

$$
\frac{\left(\mu\left(x_{1}, \cdots,\left(x_{j}+1\right), \cdots, x_{p}\right)\right)}{\left(\mu\left(x_{1}, \cdots, x_{j}, \cdots, x_{p}\right)\right)}=\exp \left(\beta_{j}\right) .
$$

Sehingga dari persamaan (2.5) dapat diinterpretasikan bahwa untuk setiap kenaikan satu unit dari nilai variabel prediktor kontinu $X_{j}$ yaitu $x_{j}$ dengan asumsi nilai variabel prediktor lainnya tetap, rata-rata nilai $Y$ cenderung naik menjadi $\exp \left(\widehat{\beta}_{j}\right)$ kali. 


\section{Data dan Metode Penelitian}

\subsection{Sumber Data dan Variabel Penelitian}

Data yang digunakan adalah data sekunder yang diperoleh dari dinas kesehatan kota Padang tahun 2013. Data jumlah kasus DBD yang meninggal di kota Padang tahun 2013 sebagai variabel respon $(Y)$ dan faktor lingkungan sebagai variabel prediktor $(X)$. Unsur-unsur yang terkait dengan faktor lingkungan yang diduga mempengaruhi variabel respon tersebut diantaranya adalah [4]:

1. Persentase rumah sehat $(X 1)$,

2. Persentase sarana air bersih yang memenuhi syarat $(X 2)$,

3. Persentase rumah ber-Prilaku Hidup Bersih Sehat (ber-PHBS) (X3),

4. Persentase pengelolaan sampah yang memenuhi syarat $(X 4)$,

5. Persentase jamban yang memenuhi syarat $(X 5)$.

\subsection{Teknik pengolahan data}

Untuk memperoleh model dengan metode regresi Poisson ini digunakan software SPSS 16.0. Berikut ini adalah langkah-langkah dalam pengolahan data sekunder:

1. Membuat statistika deskriptif untuk variabel respon (Jumlah kasus DBD yang meninggal) serta variabel prediktor.

2. Melakukan uji Kolmogorov-Smirnov untuk menentukan apakah variabel respon $(Y)$ berdistribusi Poisson. Selanjutnya dilakukan pemeriksaan overdispersi. Untuk pemeriksaan overdispersi dapat dilihat pada uji descriptive statistics, yaitu dengan melihat rasio dari varian dan nilai harapan.

3. Setelah diketahui data berdistribusi Poisson dan tidak terjadi overdispersi. Maka selanjutnya dilakukan pembentukan model regresi Poisson dengan melakukan penaksiran parameter pada model dan menentukan model yang fit terhadap data.

4. Dari model yang signifikan dilakukan uji kembali untuk mendapatkan model terbaik.

5. Menentukan nilai taksiran parameter dan Pearson residual untuk jumlah kasus DBD yang meninggal di Kota Padang.

6. Memberikan kesimpulan dan saran mengenai penelitian jumlah kasus DBD yang meninggal di Kota Padang.

\section{Hasil dan Pembahasan}

\subsection{Deskripsi Data}

Gambaran umum untuk variabel respon (jumlah kasus DBD yang meninggal) dapat dilihat pada Gambar 4.1. Berdasarkan Gambar 4.1 terdapat 22 puskesmas yang ada di Kota Padang, enam puskesmas diantaranya memiliki angka penderita yang meninggal. Jumlah meninggal tertinggi terjadi pada puskesmas Pegambiran.

Berikut adalah gambaran umum variabel-variabel prediktor dapat dilihat pada Gambar 4.1. 


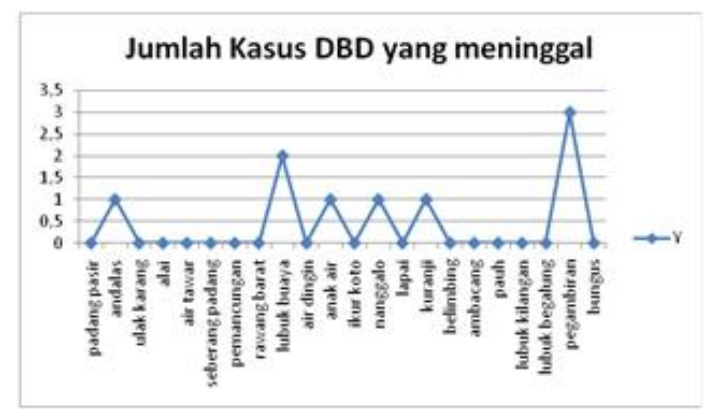

Gambar 4.1.1 Jumlah kasus DBD yang meninggal pada tahun 2013

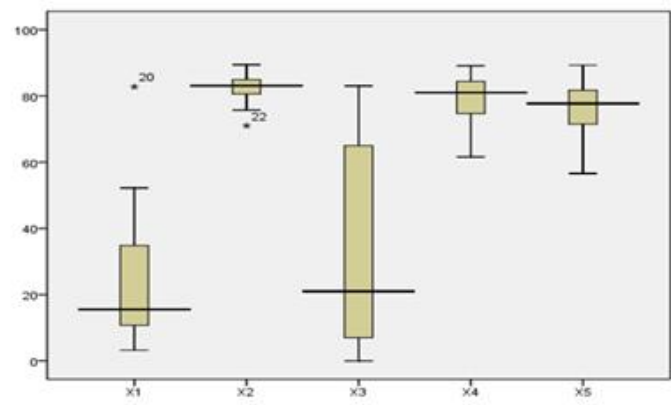

Gambar 4.1.2 Diagram kotak garis untuk semua variabel prediktor

Secara visual dari diagram kotak garis dapat menggambarkan lokasi pemusatan dan rentangan penyebaran data. Sebagaimana dapat dilihat bahwa pada $X_{1}$ dan $X_{3}$ lebih rendah di bandingkan dengan yang lainnya, artinya persentase rumah sehat dan persentase rumah ber-PHBS masih sangat rendah di Kota Padang.

\subsection{Pengujian Distribusi Poisson pada Variabel Respon Y}

Pengujian distribusi Poisson pada variabel respon $Y$ yaitu jumlah kasus DBD yang meninggal, dilakukan dengan uji Kolmogorov-Smirnov. Hipotesis uji KolmogorovSmirnov dapat dinyatakan sebagai berikut:

$H_{0}$ : jumlah kasus DBD yang meninggal berdistribusi Poisson.

$H_{1}$ : jumlah kasus DBD yang meninggal tidak berdistribusi Poisson.

Diperoleh bahwa nilai $D_{\text {hitung }}=0,063$, sementara nilai $D_{(\text {tabel })}$ adalah 0,289 dengan taraf uji $\alpha=5 \%$. Karena nilai $D_{\text {hitung }}<D_{\text {tabel }}$ yaitu $0,063<0,289$ maka $H_{0}$ diterima dan disimpulkan bahwa jumlah kasus DBD meninggal di Kota Padang mengikuti bentuk distribusi Poisson.

Untuk melakukan pemeriksaan overdispersi terhadap data dapat dilihat bahwa rasio dari nilai harapan dan varian adalah 1,5 . Karena rasio dari nilai harapan dan varian kurang dari 2,5, maka ini menunjukkan bahwa tidak terjadi kasus overdis- 
persi, sehingga regresi poisson dapat digunakan pada penelitian ini.

\subsection{Pembentukan Model Regresi Poisson}

Pembentukan model regresi Poisson, dapat dilakukan dengan cara menaksir Parameter $\beta_{0}, \beta_{1}, \beta_{2}, \beta_{3}, \beta_{4}, \beta_{5}$. Dari hasil penaksiran parameter yang dapat dilihat pada tabel, diperoleh model sebagai berikut:

$$
\widehat{\mu_{i}}=\exp \left(13.058-0.096 x_{1 i}-0,196 x_{2 i}-0,050 x_{3 i}-0,007 x_{4 i}+0,068 x_{5 i}\right)
$$

Tabel 4.3.1 Estimasi Parameter Model Regresi Poisson dalam Pemodelan jumlah kasus DBD yang meninggal

\begin{tabular}{|c|c|c|c|}
\hline Parameter & Estimasi & Standar Error & P-Value \\
\hline (intercept) $\beta_{0}$ & 13.058 & 9.5361 & .171 \\
\hline$\beta_{1}$ & -.096 & .0544 & .079 \\
\hline$\beta_{2}$ & -.196 & .1757 & .268 \\
\hline$\beta_{3}$ & -.050 & .0229 & .028 \\
\hline$\beta_{4}$ & -.007 & .1112 & .950 \\
\hline$\beta_{5}$ & .068 & .1258 & .590 \\
\hline
\end{tabular}

Berdasarkan Tabel 4.3.1 dengan taraf signifikansi $\alpha=10 \%$, dapat dilihat bahwa terdapat dua parameter yang nilai $p-$ value $<\alpha$ yaitu $\beta_{1}$ dan $\beta_{3}$.

Selanjutnya, dilakukan pengujian kembali terhadap parameter yang signifikan. Untuk melihat apakah parameter yang signifikan berpengaruh terhadap variabel respon $(Y)$.

Berikut adalah estimasi parameter dan nilai $p$ - value model regresi Poisson.

Tabel 4.4.1 Estimasi Parameter Model Regresi Poisson dalam Pemodelan jumlah kasus DBD yang meninggal dengan parameter $\beta_{1}$ dan $\beta_{3}$.

\begin{tabular}{|c|c|c|c|}
\hline Parameter & Estimasi & Standar Error & P-Value \\
\hline (intercept) $\beta_{0}$ & 1.358 & .6506 & .037 \\
\hline$\beta_{1}$ & -.078 & .0414 & .059 \\
\hline$\beta_{3}$ & -.046 & .0196 & .019 \\
\hline
\end{tabular}

Berdasarkan Tabel 4.4.1 dengan taraf signifikansi $\alpha=10 \%$, dapat dilihat untuk semua nilai $p-$ value $<\alpha$, sehingga dapat dibentuk model sebagai berikut:

$$
\widehat{\mu_{i}}=\exp \left(1.358-0.078 x_{1 i}-0,046 x_{3 i}\right) .
$$

Dari kedua model yang diperoleh dapat dipilih model terbaik, dengan kriteria pemilihan model terbaik yang digunakan adalah

(1) AIC (Akaike Information Criterion)

(2) BIC (Bayesian Information Criterion)

Model terbaik adalah model dengan nilai AIC dan BIC yang terkecil. Berikut rangkuman nilai AIC dan BIC masing-masing model. 
Tabel 4.4.1 Statistik Uji Model Terbaik

\begin{tabular}{|c|c|c|}
\hline Regresi Poisson & AIC & BIC \\
\hline Model ke-I & 29,899 & 36,445 \\
\hline Model ke-II & 25,637 & 28,910 \\
\hline
\end{tabular}

Dari Tabel 4.4.1 tersebut dapat dilihat bahwa model ke-II dari regresi Poisson memiliki nilai AIC dan BIC lebih kecil dibandingkan model ke-I, sehingga dapat disimpulkan bahwa model terbaik adalah regresi Poisson dengan model ke-II, yaitu

$$
\widehat{\mu_{i}}=\exp \left(1.358-0.078 x_{1 i}-0,046 x_{3 i}\right) .
$$

Adapun interpretasi dari model di atas adalah

(1) Persentase rumah sehat (X1). Rata-rata jumlah kasus DBD yang meninggal cenderung turun menjadi $\exp (-0.078)=0,92$ kali jika persentase rumah sehat naik $1 \%$ dengan asumsi bahwa variabel prediktor lain konstan.

(2) Persentase rumah ber-PHBS (X3). Rata-rata jumlah kasus DBD yang meninggal cenderung turun menjadi $\exp (-0.046)=0,95$ kali jika persentase rumah ber-PHBS naik $1 \%$ dengan asumsi variabel prediktor lain konstan.

\section{Kesimpulan}

Jumlah kasus DBD yang meninggal dengan menggunakan regresi Poisson, diperoleh model sebagai berikut:

$$
\widehat{\mu_{i}}=\exp \left(1.358-0.078 x_{1 i}-0,046 x_{3 i}\right) .
$$

Berdasarkan kriteria pemilihan model terbaik AIC dan BIC, dapat disimpulkan bahwa variabel prediktor yang berpengaruh terhadap jumlah kasus DBD yang meninggal adalah Persentase rumah sehat dan persentase rumah ber-Prilaku Hidup Bersih Sehat (ber-PHBS).

\section{Daftar Pustaka}

[1] Bozdogan, H. 2000. Akaike Information Criterion and Recent Development in Information Complexity. Journal of Mathematical Psychology. 44 : 62 - 91.

[2] Cameron, A. Colin and P. K Trivedi. 1998. Regression Analysis of Count Data. Cambrige University Press, New York.

[3] Departemen Kesehatan RI. 2005. Tata Laksana DBD. Depkes RI, Jakarta.

[4] Departemen Kesehatan RI. 2004. Penanggulangan Bencana DBD. Depkes RI, Jakarta.

[5] McCullagh, P. and J. A. Nelder. 1989. Generalized Linear Models. Second Edition. Chapman and Hall,London

[6] Dinas Kesehatan Kota Padang. 2014. Profil Kesehatan Tahun 2013. Dinkes Kota Padang, Padang

[7] Siegel, S. 1992. Statistika Nonparametrik. Gramedia Pustaka Tama, Jakarta.

[8] Walpole, R. E. 1982. Pengantar Statistika. Edisi ketiga. Gramedia Pustaka Tama,Jakarta. 